\title{
INTERNALIZATION OF MODERATE VALUES OF ISLAM IN THE DEVELOPMENT OF COMMUNITY-BASED VILLAGE COMMUNITY LITERATION: \\ A Case Study of Kita Belajar Mandiri Literacy Community
}

\author{
Ahmad Sholeh*, Sigit Priatmoko** \\ Pendidikan Guru Madrasah Ibtidaiyah, Universitas Islam Negeri Maulana Malik Ibrahim, Malang, Indonesia
}

email: *sholeh_76@yahoo.com, ${ }^{* *}$ sigitpriatmoko@uin-malang.ac.id

\section{ABSTRACT}

This study aims to comprehensively reveal the construction of moderate values of Islam developed by Kita Belajar Menulis (KBM) literacy community in Bojonegoro and how these values were internalized to their members. This research employed a case study design. Data were collected using observation, interviews, and documentation techniques. The data collected was analyzed using an interactive analysis model that included data collection, data reduction, data display, and concluding. The results showed that the moderate values of Islam developed by KBM in Bojonegoro were based on equality values. Then it developed into pluralism, authenticity, brotherhood, tolerance, and progressiveness. To internalize these values, KBM used four strategies that included giving reinforcement, modeling, habituation, and discussion, so that the moderate values of Islam are properly internalized.

\section{ABSTRAK}

Penelitian ini bertujuan untuk mengungkap secara komprehensif konstruksi nilai-nilai moderat Islam yang dikembangkan oleh komunitas literasi Kita Belajar Menulis (KBM) di Bojonegoro dan bagaimana nilai-nilai tersebut diinternalisasikan kepada anggotanya. Penelitian ini menggunakan desain studi kasus. Teknik pengumpulan data menggunakan observasi, wawancara, dan dokumentasi. Data yang dikumpulkan dianalisis menggunakan model analisis interaktif yang meliputi pengumpulan data, reduksi data, tampilan data, dan penarikan kesimpulan. Hasil penelitian menunjukkan bahwa nilai-nilai moderat Islam yang dikembangkan oleh KBM di Bojonegoro berlandaskan pada nilai kesetaraan. Kemudian berkembang menjadi pluralisme, autentisitas, persaudaraan, toleransi, dan progresif. Untuk menginternalisasikan nilai-nilai tersebut, KBM menggunakan empat strategi yang meliputi pemberian reinforcement, modeling, pembiasaan, dan diskusi, sehingga nilai-nilai moderat Islam terinternalisasi dengan baik.
ARTICLE HISTORY

Received 9 December 2019

Accepted 5 June 2020

\section{KEYWORDS}

Moderate values of Islam; literacy; community; Kita Belajar Menulis (KBM) 


\section{Introduction}

Various studies made on literacy culture in Indonesia showed alarming results. For example, the UNESCO findings state that the index of interest in reading of Indonesian people only reached 0.001 . That number indicates that of every 1,000 Indonesian, there is only 1 person who has an interest in reading. Moreover, the average Indonesian people only read zero to one book a year. This condition is below that of other ASEAN countries where people read two to three books a year. It will be lamer compared to the United States citizen, whose reading level reaches 10-20 books a year. ${ }^{1}$

Studies conducted by the PISA (Programme for International Student Assessment) also received similar results. A study in 2012 showed Indonesian students ranked $64^{\text {th }}$ with a score of 396 (average score of OECD 496) (OECD, 2013) out of 65 countries participated in PISA 2009 and 2012. Indonesia remained in $64^{\text {th }}$ place in PISA 2015 out of 72 countries. This means there is an increase of only a number from 396 in PISA 2012 to 397 in PISA 2015. This increase is not significant enough when the application of the text-based curriculum in 2013 has been in force for two years before text-based PISA in $2015 .^{2}$

This lack needs to be resolved considering the fact that literacy in the current information age has become primary needs. Nowadays, global society is demanded to be able to adapt to technological progress and renewal. This was stated in the Prague Declaration (UNESCO, 2003) which emphasizes the importance of information literacy such as the ability to search, understand, evaluate, and manage information critically into useful knowledge for the development of one's personal and social life. ${ }^{3}$ The absence of information literacy might make it easier for the public to be affected by hoax issues. According to Catts and Lau, adequate information literacy can prevent people from the tendency to quickly believe in the news that circulates without checking the truth in advance. ${ }^{4}$

Besides hoaxes, SARA issues (SARA refers to Suku, Agama, Ras, dan Antargolongan-ethnicity, religion, race, and inter-group relations; public discussion of any of which was taboo during the New Order) can also be easily spread and trusted by the public without further study. A

\footnotetext{
1 Ane Permatasari, "Membangun Kualitas Bangsa dengan Budaya Literasi," Prosiding Seminar Nasional Bulan Bahasa 2015 (Bengkulu: Unit Penerbitan FKIP Universitas Bengkulu, 2015), p. 146-156.

${ }^{2}$ Satgas Gerakan Literasi Sekolah Kemendikbud, Desain Induk Gerakan Literasi Sekolah, eds. Rangesti Wiedarti and Kisyani Laksono (Jakarta: Kementerian Pendidikan dan Kebudayaan, 2018)

${ }^{3}$ Ibid.

${ }^{4}$ Christiany Juditha, "Literasi Informasi Melawan Hoaks Bidang Kesehatan di Komunitas Online," Jurnal Ilmu Komunikasi, vol. 16, no. 1 (June, 2019): 79, https://doi.org/10.24002/jik.v16i1.1857.
} 
representative example of the danger of a lack of literacy culture in society is the recent number of riots and socio-religious conflicts. The community is easily provoked by sensitive information related to SARA produced and distributed by irresponsible groups. Therefore, the solution to the issues of radicalism and terrorism can be done through civilizing literacy. In the lower class society, for example, apart from political interests, many people disbelieved and cursed one another due to the polemic of blasphemy. This eventually spills over into cyberspace with the spread of hoax news where mutual slander continues to occur, where people suddenly become the law or the God for others. Romo Haryatmoko said that people could be arbitrary in treating others. Someone suddenly becomes an "executioner" who is so devilish to crush the joints of humanity. ${ }^{5}$ This is where the importance of the literacy culture of the community as a forum for information and education.

Aware of this condition, the government through the Ministry of Education and Culture issued a policy of enhancing the culture of national literacy trough the Gerakan Literasi Nasional or GLN (National Literacy Movement) program that was set on March 25, 2016. GLN functions as a forum that synergizes literacy movements carried out by various government sectors to avoid overlapping superimposed. The main goal is that literacy can be achieved maximally. The Ministry of Education and Culture employed a duplication method by determining the targets with a limited amount, improving infrastructure quality, implementing of activities as much as possible, and influencing the target or the surrounding areas.

The national literacy movement or GLN has a broad scope, namely schools, families, and communities. The movements begin whenever there is a growing interest in reading. The Ministry of Education and Culture employed a bottom-up approach. Existing human resources were mobilized to carry out interest in reading campaigns through engaging literacy activists. This action was conducted due to the failure of growing interest in reading has been caused by the approach taken which tended to be structural instead of functional. For example, a regional library that only opens following the work hours of its employees. Additionally, the programs launched were also not based on community aspirations. ${ }^{6}$

\footnotetext{
${ }^{5}$ Muhammad Aziz Hakim, et. al., Moderasi Islam: Deradikalisasi, Deideologisasi dan Kontribusi untuk NKRI (Tulungagung: IAIN Tulungagung Press, 2017), p. ix-X.

${ }^{6}$ Billy Antoro, Gerakan Literasi Sekolah dari Pucuk hingga Akar: Sebuah Refleksi (Jakarta: Kementerian Pendidikan dan Kebudayaan, 2017)
} 
The existence of literacy communities amid society is the answer to these problems. The formation of a literacy community shows that the community begins to aware of literacy. This has become a valuable social capital for the development of a national literacy culture. Through community involvement, community participation in GLN can be increased. Kita Belajar Menulis (KBM) community is one of the literacy communities that grow in rural areas. The community established on October 17, 2017 has the main objective to raise awareness of the literacy of the surrounding community. KBM is based in Kedungsari, Kepoh Village, Kepohbaru District, Bojonegoro Regency.

Slamet Widodo, a Mathematics teacher at MTsN 3 Bojonegoro, founded this community. In a relatively short time, this community has contributed to fostering a literacy culture in Bojonegoro, especially around Kepohbaru District. KBM not only focuses on realizing the importance of literacy but also trains its members to improve their writing skills. Although it is relatively new, KBM has been widely known by communities in Bojonegoro. Some of its members have even succeeded in publishing not only indie books but also major books. Besides, they also have published extensively in various mass media, both online and printed media.

In addition to awareness of the urgency of literacy and writing training, KBM also tries to facilitate its members to develop their soft skills under their respective talents and interest. Character education based on moderate values of Islam is also conducted. Its management is aware of the importance of inculcating moderate values of Islam to make literate members of KBM able to contribute to counter hoax issues, especially those related to SARA issues.

In this context, this study finds its relevance and urgency. The development of literacy culture shall be accompanied by the inculcation of moderate values of Islam and various life skills that can be useful for the community. It is expected that society might not only be literate but also be more prosperous and independent in life. From this background of the study, the researchers were interested in investigating further and comprehensively about the internalization of moderate values of Islam in the development of a community-based village community literacy culture (a case study of Kita Belajar Menulis (KBM) in Bojonegoro).

\section{Method}

This study employed a qualitative approach in the form of a case study. The approach and the method used were based on a core of the study that was expected to reveal the process of 
internalizing the moderate values of Islam in a rural community at KBM Bojonegoro. The presence of researchers at the study site was as observers. The researchers followed how the research subjects run a program of activities, interactions among members, and various other aspects that support the expected data collection.

In this study, the data were classified into two categories, primary and secondary data. Primary data were in the form of utterances, actions, and activities of informants that were directly related to the internalization of moderate values of Islam in a rural community in KBM Bojonegoro. Secondary data were in the form of field notes and documents supporting KBM in internalizing moderate values of Islam into its members.

Along with the data types, the data sources in this study were also divided into two categories, namely key informants and non-key informants. Key informants included KBM founders, chairpersons, secretaries, treasurers, other daily managements, and KBM members. Meanwhile, non-key informants consisted of people around the center of the KBM in the Kepohbaru District as well as the literacy community around Bojonegoro who had collaborated with KBM.

Data processed in this study were collected using interviews, observation, and documentation techniques. The collected data was then analyzed using Miles and Huberman's interactive analysis model that included data collection, data reduction, data display, and concluding. As for checking the validity of the data, the triangulation technique was done which included triangulation of data sources, data collection methods, and extension of observation.

\section{Findings}

\section{Construction of Moderate Values of Islam in KBM}

Kita Belajar Menulis (KBM) is a writing community located in Kedungsari, RT 15 RW 06, Kepoh Village, Kepohbaru District, Bojonegoro Regency. This community was formed on October 17, 2017, by its founder, a Mathematics teacher at MTSN 3 Bojonegoro named Slamet Widodo along with two of his students, namely Roni Hardiawan and M. Arfi Nur Iksan. As Widodo said, the establishment of KBM was motivated by the lack of a writing community in the Bojonegoro Regency, especially in rural areas such as Kepohbaru District and its surrounding areas. Widodo was then moved to establish his writing community. He invited his two students, Hardiawan and Iksan, to discuss plans to establish the community at 
his residence on Tuesday night, October 17, 2017. They then gave the name to the community as Kita Belajar Menulis (KBM). Its main purpose in establishing KBM is to be a forum for village youths to learn to write.

According to Widodo, the potential to improve the literacy culture of rural youth is not inferior to urban youth who get more education facilities and services. Widodo's statement shows that KBM has the basic principles and philosophy of equality. The choice of the name $\mathrm{KBM}$ is also following Widodo's passion that the community he founded will be able to be a house of shared learning that promotes a sense of kinship among its members. Widodo wants $\mathrm{KBM}$ to be open to anyone and its members are free from anywhere. This family atmosphere is a distinction between KBM and other writing communities. Luthfiah Fajrianti, a KBM member from Tasikmalaya Regency, West Java, also conveyed the same thing as follows:

"After joining KBM, I felt a strong bond of ukhuwah islâmîyah. Even though I am a new member, I often get motivation and support from other friends. Yesterday, it was said by Mr. Widodo that KBM members are family. KBM is indeed different from most communities."

KBM does not pressure and forces its members to immediately publish a book as proof that they have become writers. Instead, KBM members were freed to explore themselves in the world of authorship. As a writing community, KBM develops a curriculum that is indeed focused to equip and train the skills of its members in writing. The background of KBM members is very diverse, in terms of both competence or ability to write as well as educational background, professions, religious community organizations, tribes, and languages.

This principle, which was held firmly from the moment it was established, has caused enthusiasts to be members of KBM from not only Kepohbaru District and the surrounding area but has expanded to outside the province. Up to now, there have been three KBM members from outside East Java, two from West Java (Tasikmalaya Regency and Pandeglang Regency), and one from Bukti Tinggi, West Sumatra.

${ }^{7}$ Lutfiah Fajrianti, interview via WhatsApp, 15 October 2019, at 19.52. 
From the description above, simply put, the construction of moderate values of Islam developed by KBM can be described as follows:

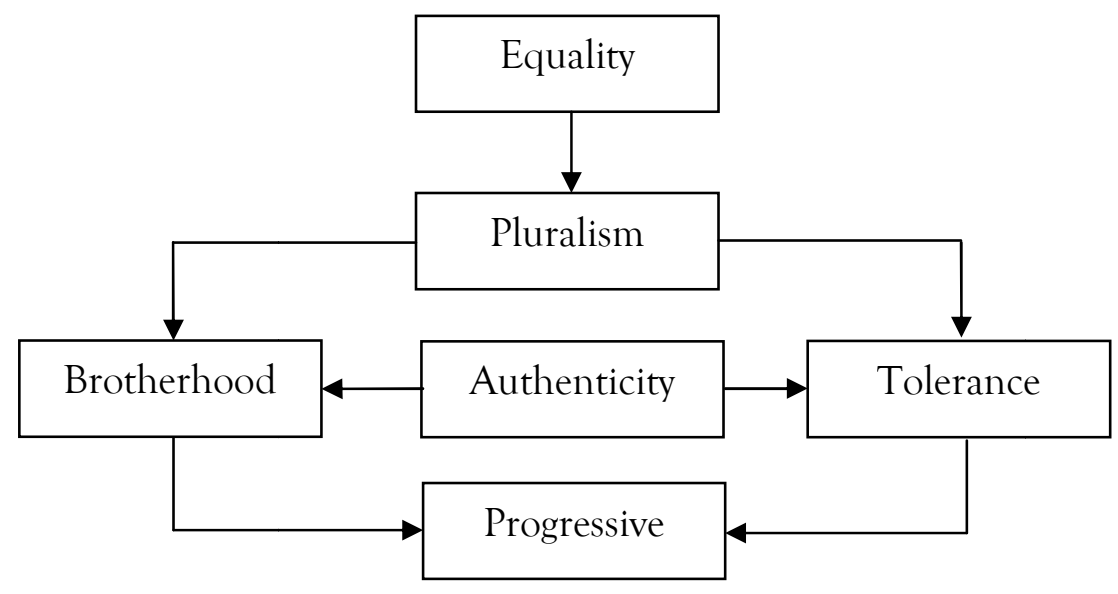

Construction of Moderate Values of Islam at KBM

\section{The Strategy for Internalizing Moderate Values of Islam at KBM}

KBM does not explicitly include the internalization of moderate values of Islam as one of its programs. The internalization process of these values naturally runs at the KBM, which later became a culture of values that forms the foundation of KBM. Several KBM programs that are a means of internalizing moderate values of Islam were described as follows.

First, member recruitment. KBM does not regularly open vacancies for new members, but every opportunity is opened for anyone who wants to join as a member. Nevertheless, there is a recruitment process and requirements that must be met and fulfilled by prospective members. There are two stages in the recruitment process at the KBM; interview and submit three pieces of writings. Interviews are usually conducted to find out the motivation and how strong the commitment of prospective members to learn to write at KBM. Furthermore, interviews are also used to find out the background of prospective members and to socialize the culture of moderate values in the KBM. The management shall transmit certain rules and regulations in the KBM relating to the ethics of communication and the content of the text which are prohibited from affecting the SARA issue (ethnicity, religion, race, and inter-group relations).

Second, themed writing. This program is carried out with a mechanism every 10 days all KBM members are required to submit writings with certain themes that have been mutually agreed upon. The theme is chosen by accepting proposals and then voting. The theme with the most votes is then agreed to be the theme for writing for the next 10 days. If the member is late in submitting the themed writing until the deadline, then the submission is considered debt that remains to be paid even though the theme of the writing has changed. If the member does 
not submit themed writing or writings for three times, a warning letter will be given by the management. If this warning letter is not heeded, then the member will be expelled from the KBM. Members who are expelled can rejoin KBM. However, they still have to go through procedures when they first register to the community.

Programs at KBM aimed to improve writing skills, improve discipline, to test the seriousness, and to learn the commitment of the KBM members. Writings submitted at KBM must comply with the requirements, namely: (1) the writings have been edited in advance to make sure there will be no typos; (2) the writings is original work and not the results of plagiarism or copy-paste from other works; and (3) the writings do not contain hoax, expression of hatred, provocative sentences, and SARA. If these conditions are not met, especially in point 2 and 3, the member in question will immediately be expelled from the KBM. According to Slamet Widodo and Muhammad Alim, this action is to maintain the conduciveness and neutrality of the KBM. As its main purpose, KBM is a community of learning to write, not affiliated with certain groups and parties. In connection with this, Rahayu Lestari Putri as a member of KBM said as follows:

"As Mr. Widodo, Mr. Alim, and other managements often say, KBM is open to anyone. We never question members' religious backgrounds. The important thing is he or she commits to learning to write. The main purpose of KBM is indeed to accommodate people who want to learn to write instead of people's beliefs. Thus, we are neutral. Those from NU, Muhammadiyah, or others can stay united as one family in this community."

Third, ngopi literasi. Although the main base is online, through the WhatsApp group, KBM also organizes direct meetings through a program called ngopi literasi (coffee literacy). This program was used as a means to discuss evaluating the implementation of KBM programs, various members' problems, and future targets and plans. Moreover, the board also sought to take advantage of this opportunity to instill mutual respect and appreciation for the work of others.

Fourth, kopi darat (abbreviated as kopdar). Kopdar is a program where all KBM members meet in a forum either formal, such as seminars or workshops or informal, a simple workshop at the residence of one of its members. This program is carried out every six months. Currently, KBM has held 4 gatherings. Two of them were in the form of seminars and workshops. This kopdar opportunity was used by the management to strengthen the building of moderate values

\footnotetext{
${ }^{8}$ Rahayu Lestari Putri, interview, Sunday, 13 October 2019, at 14.05.
} 
culture in the KBM. One of them is to strengthen the family ties among KBM members and to improve skills as well as to expand the knowledge of KBM members in the creative writing process that is beneficial to others. Kopdar also functions as a means of exchanging the latest experiences and knowledge about the world of authorship. Usually, kopdar is also used as a reference by the KBM management to evaluate existing programs and formulate new programs.

Fifth, anthology book. This program aims to increase the confidence of KBM members that they can write books even though the book is written in the form of an anthology. The process of implementing this program starts from: (1) internal management discussion to determine the persons in charge of writing books and editors; (2) the persons in charge then formulate the implementation mechanism; (3) announce to KBM members in the WhatsApp group as well as open the proposed theme; (4) after the theme is agreed upon, the persons in charge responsible for formulating the systematic and format of writings; (5) KBM members write according to the agreed theme before the deadline; (6) Submitted writings are then edited until they are eligible to be sent to the publisher; and (7) KBM members are required to pay fees according to the price of the book.

Sixth, online writing classes and online writing seminars. Online writing classes program was originally held open to the public, people outside the KBM members were invited to participate. However, along with the number of enthusiasts and effectiveness considerations for KBM members themselves, the online writing classes program was changed to specifically for KBM members. As for the interest of the public who are interested in learning to write, KBM created a program in the form of an online writing seminar.

\section{Discussion}

\section{Construction of Moderate Values of Islam in KBM}

The discourse on moderate values of Islam has recently become a hot issue. This is inseparable from the phenomenon of the religious diversity of Muslims who are experiencing dynamics in the form of turbulence and distortion in various dimensions. This phenomenon is related to the issues of Islamic revivalism that have successfully created endless turmoil in the Islamic society, especially in the Middle East region. Indonesia, as the country with the largest Muslim population, is thus affected by this phenomenon. The emergence of fundamentalism and radicalism that then leads to cases of terrorism in Indonesia can be valid evidence thereof. 
Various efforts both repressive-reactive and preventive have been carried out by governments and communities from various walks of life. This study focused on the latter. One of these preventive measures was conducted to mainstream religious moderation. The government through the Ministry of Religious Affairs is incessantly promoting the moderate values of Islam to the people. No half-hearted promotion of religious moderation has been included in the National Medium-Term Development Plant 2020-2024 Ministry of Religious Affairs of the Republic of Indonesia.9 Thus it can be said, religious moderation is currently a national strategic issue.

Moderate Islam can be interpreted literally as Islam that puts forward a middle attitude, that is, it is not extreme-fanatical about one belief. This terminology is one of the many terminologies used to label Muslims, such as liberals, modernists, and reformers. However, according to Khaled Abou El Fadl, moderate is the most appropriate terminology among others. ${ }^{10}$ This is supported by various sacred texts which state that Muslims are the middle of the umma as well as various calls for Muslims to behave fairly, respect each other, tolerance, and so on. Moderate thus can also be called the basic identity and character of Islam itself.

As elaborated in the previous section, the establishment of the KBM was motivated by the lack of literacy communities in Bojonegoro Regency, especially those focused on developing the writing skills of young people in remote villages. The scarcity of this literacy community has sparked concern for Widodo, Hardiawan, and Iksan, considering the dangers of hoaxes that always lurk in the community. Rural people are no exception. It is known that hoaxes are one of the strategies as well as weapons used by extremists to carry out propaganda. Through KBM, its founders expected to be able to contribute and invite the community, especially rural youth to take an active role in preventing hoaxes.

Starting from the spirit of preventing hoax, the culture built on KBM if comprehensively analyzed also shows the construction of moderate values of Islam. Based on the results from the data collection, it was found that the KBM was built based on the value of equality. Its founders believe that rural youth also have the same developing potential as urban youth who

9 Benny Andriyos, "Menag: Moderasi Beragama, Jantung Kemenag," Kemenag, 10 July, 2019, http://www.pendis.kemenag.go.id/new/2019/07/10/menag-moderasi-beragama-jantung-kemenag/, accessed 10 July 2019.

10 Sauqi Futaqi, "Konstruksi Moderasi Islam (Wasathiyyah) dalam Kurikulum Pendidikan Islam," Proceedings of $2^{\text {nd }}$ Annual Conference for Muslim Scholars (Surabaya: Kopertais Wilayah IV, 2018), p. 521-530. 
have better access to education. This equality value then became a milestone or foundation for the development of other values.

This equality value then met the reality of diverse of KBM members. The members of the KBM have a different background in terms of both educational background, occupation, skills, to religious understanding. This plurality has no negative impact on cohesion among KBM members. Instead, it will be a separate asset and capital for the development of KBM. Responding to this fact, the management of $\mathrm{KBM}$ does mutual respect for differences that exist. This is based on the awareness that humans are born to bring the nature of each or fithrah in terms of character and potentials that are ready to be developed.

Further, KBM also tried to build the confidence of its members as village youth. Identity as a villager must be pride. This was later outlined in the KBM vision, "Building the Writing Tradition of Village Youth." The founders and management of KBM aspire, KBM members grow to be authentic individuals, who do not forget the roots of their history, customs, traditions, and culture. Awareness of this authenticity requires KBM members to have an attitude of tolerance. Realizing this, the management of KBM continues to strive to cultivate an attitude of tolerance and mutual respect for fellow members. The steps taken were to strengthen the sense of kinship between members. For example, to summon members, the management makes use of the call "KBM Family" by visiting the sick members, attending invitations of members who have an event, and so on. This effort is effective in increasing cohesiveness among KBM members.

Mainstreaming the attitude of tolerance was also realized through the rules of writing. As presented in the previous section, KBM requires its members not to touch on sensitive issues such as SARA, hate speech, hoaxes, discrimination, and various other negative things. Armed with the construction of these values, KBM members continue to strive to improve the quality of their work. The spirit of learning and work continues to be echoed every day in the KBM group. The administrator/management always gives credit to the work of the KBM members in the hope that their motivation will be maintained. The provision of criticism and advice is done with decent language in order not to offend the members concerned. This progressive spirit shows that there is also a progressive value in the culture of KBM.

\section{The Strategy for Internalizing Moderate Values of Islam at KBM}

Education is a human right. Education is also a process of building a human mindset from birth to death. At first, the objective of Indonesian education was pragmatic (termed non vitae 
sed scholae discimus). With an emphasis on the economic sector, especially through industrialization, the state expects to improve the welfare and prosperity of the entire Indonesian nation and achieve social justice. Then, education became a producer of skilled labor but did not produce virtuous people. During the multidimensional crisis, pragmatic education made the situation even worse. ${ }^{11}$

Pragmatic education produces people who are intelligent and skilled, but not necessarily virtuous. Many problems can be used as indicators, ranging from social, political, racial, environmental issues, piety, immorality, and nationalism. Each refers to the conclusions that human resources (which incidentally are produced by pragmatic education) are lacking in terms of the humanities. It is at this point that value education finds its urgency.

In his theory of value education, Douglas P. Superka puts forward five approaches that can be used: (1) the inculcation approach; (2) the cognitive moral development approach; (3) the value analysis approach; (4) the value clarification approach; and (5) action learning approach. ${ }^{12}$ Referring to the findings presented in the previous section, the strategy adopted by KBM to internalize the moderate values of Islam was in line with Superka's theory, although not as a whole, especially in the value inculcation approach and direct experience approach. There were four strategies implemented by $\mathrm{KBM}$ to internalize the moderate values of Islam to its members. The four strategies were integrated with the implementation of the six flagship KBM programs: (1) interviewing prospective new members; (2) themed writing; (3) ngopi literasi; (4) kopdar; (5) writing an anthology book; and (6) online writing class and online writing seminar. The four strategies were described as follows:

\section{1) Reinforcement}

The first approach offered by Superka to internalize values is the inculcation approach. As the name suggests, the main purpose of this approach is to instill values that are considered necessary. This approach views values as standards or rules of conduct that come from the community or culture. While the value in this approach is considered as a process of identification and socialization where a person, sometimes unconsciously, takes standards or norms from another person, group, or community, and incorporates them into his or her value system. Various methods might be done in this approach. One of the

\footnotetext{
${ }^{11}$ Qiqi Yuliati Zaqiah and A. Rusdiana, Pendidikan Nilai: Kajian Teori dan Praktik di Sekolah (Bandung: Pustaka Setia, 2014)

${ }^{12}$ Douglas P. Superka, et. al., Values Education Sourcebook: Conceptual Approaches, Materials Analyses, and an Annotated Bibliography (California: Social Science Education Consortium, 1976)
} 
most widely used and proven effective is the reinforcement method. This method includes giving positive reinforcement such as giving appreciation to students who show behavior per certain values or giving negative reinforcement in the form of punishment to students who show behavior in contrast to the internalized values.

Reinforcement will make the child repeat the behavior he or she likes. This reinforcement can be in the form of positive reinforcement and negative reinforcement. Both kinds of reinforcements play an important role in the process of forming selfregulation in children while learning in class. Self-regulation is an ability possessed by humans in the form of the ability to think. Along with that ability, they can manipulate the environment, resulting in changes in the environment due to human activities. ${ }^{13}$

The purpose of providing reinforcement is three, namely increasing students' attention to lessons, stimulating and increasing learning motivation, and increasing learning activities and fostering productive behavior. The results of the study showed that reinforcement played a role in the self-regulation of students in learning in class. The reinforcement occurred is divided into two aspects, positive and negative reinforcement.

The application of this reinforcement method can be seen in giving appreciation in the form of praise to KBM members who send their writings and if they succeed in achieving an achievement, for example winning poetry creative competitions, writing short stories, or successfully publishing books. These works must be by the rules of the KBM, which do not involve sensitive issues such as SARA, discredit other groups, and do not contain hoaxes.

The implementation of this method can also be seen in the culture of interaction at KBM. For example, when there are members who send their work to the WhatsApp group, the management invited the members to give appreciation for the work. These positive responses so far are considered effective in motivating KBM members to continue working. If the work is not following the KBM rules, negative reinforcement is applied. The negative reinforcement is usually in the form of warnings and personal guidance.

\section{2) Modeling}

Another method that is also effective for instilling value is modeling. This method requires a figure specifically as a model of the value developed. The teacher can be a model for students. Additionally, students can also be models for other students. The

${ }^{13}$ Berliana Henu Cahyani, "Peran Reinforcement dalam Kemampuan Regulasi Diri pada Siswa SD Selama di Kelas," Jurnal Spirits, vol. 3, no. 1 (2012): 1-13, https://doi.org/10.30738/spirits.v3i1.1121. 
management, especially in the themed writing program, carried out the implementation of the modeling method in the KBM. For example, in the context of avoiding SARA issue in writing or sharing a written link which source cannot be accounted for. Moreover, in terms of tolerance, KBM management also provides examples of how writing does not offend different groups or ethnicities.

This method is commonly used in character education. In the context of Islam, this method also has gained legitimacy for it had been exemplified by the Prophet Muhammad in the process of preaching. As in the saying, which states that, the main purpose of the treatise is to improve human morals. What the Prophet Muhammad did was also strengthened by the Qur'an which states that he was a role model to be emulated by mankind, in al-Ahzzâb [33]: 33, al-Qalam [68]: 1-4, and al-Furqân [25]:32.

Attitude is a person's tendency to accept or reject an object based on values that are considered good or bad. Thus, growing an attitude means teaching and getting used to accept or reject an object. This is where the role of parents as responsible for children's education to provide a correct understanding of an object. Because the evaluation of the object as something that is useful/valuable or not useful/valuable is an internal ability that plays a role in taking action, especially when there are various possibilities for action or several alternatives are available. ${ }^{14}$

The formation of attitudes can be done through exemplary which is the process of assimilation or the process of modeling. One character of a developing child is his desire to imitate. Things that are imitated are the behaviors that are exhibited or performed by the person who becomes his role model. The principle of imitation is called modeling. Modeling is the process of imitating children against others who become their idols, role model, or people they respect.

Modeling usually starts with feeling amazed. The child is amazed at the intelligence of others, for example with the teacher whom he thinks can do everything he cannot do. Gradually, the feeling of admiration will affect his emotions and slowly the child will imitate the behavior of his role model. Because children are longer in the family, then parents should be able to set a good example and make themselves the role model for their children.

14 Hafsah Sitompul, "Metode Keteladanan dan Pembiasaan dalam Penanaman Nilai-nilai dan Pembentukan Sikap pada Anak,” Darul Ilmi: Jurnal Ilmu Kependidikan dan Keislaman, vol. 4, no. 1 (January, 2016) 


\section{3) Habituation}

Value education cannot be equated with the process of transformation of knowledge since it requires a process, time, and energy that cannot be done in a short time. As stated by Kohlberg, that the process of internalizing values includes: first, fostering and developing the structure and potential/components of intellectual experience (affective component and experiences) or "identity" or the conscience of man or the conscience (qalb) of humans with a set of moral-norm values. Second, fostering the process of experiencing and/or transactions/interactions of one's affective to enable the process of clarification of moralnorms, proposals of moral-norms (moral judgment), or reasoning of moral-norms (moral reasoning) and/or control of moral-norms (moral control). ${ }^{15}$

The two stages stated by Kohlberg indicate that the process of internalizing values requires habituation. In line with this, the $\mathrm{KBM}$ in internalizing the moderate values of Islam also took a habitual step that was integrated with the implementation of its programs. For example in the themed writing program. As explained earlier, this program besides having the main objective of training the writing skills of KBM members also aims to get them used to be moderate.

In the themed writing program, some terms and conditions must be obeyed by all KBM members without exception. In addition to the terms and conditions relating to writing and linguistic rules, several terms and conditions lead to habituation to moderate. These terms and conditions are: (1) the written writing does not relate to SARA issues; (2) the writing does not contain information that does not have a credible source; (3) the writing does not contain a hoax; (4) the writing does not contain expressions of hatred and discrediting to certain groups; and (5) provide benefits to others.

\section{4) Discussion}

This strategy aims to help KBM members use logical thinking and scientific inquiry procedures to deal with the issue of values. Like moral development, this approach also emphasizes rationality. KBM members are urged to provide verifiable facts about the goodness or value of the phenomenon. Judging is a cognitive process to determine and justify those facts.

\footnotetext{
${ }^{15}$ Rusdiana, Pendidikan Nilai.
} 
This strategy is applied when commenting on members' themed writings submitted in the WhatsApp group, especially if the contents of the writings can spark deeper discussion related to social, religious, political, economic, contemporary, and education issues. The management used this opportunity to invite their members to do a simple analysis and draw a conclusion. Apart from the themed writing program, this approach is also applied during the implementation of the ngopi literasi program. Although it does not exactly match the approach promoted by Superka, it does not reduce its substance.

During the discussion, the management also allowed members to exchange opinions and experiences about the world of authorship and actual issues surrounding socio-religion. The discussion provides maximum opportunities for members to explore their knowledge and then integrate it with the opinions of other members. Not only mature thoughts, respect the opinion of others, realize that there are opinions outside of their opinions, KBM members also feel valued as individuals who have potentials, abilities, and innate talents. During the discussion, it is normal for debates between members of the KBM, especially relating to moral issues that might present a dilemma.

Veugelers argues that one of the ways that can be used to teach values in character education is the cognitive moral development approach wherein discussion about moral cases educators can take on the role of participants or non-participants. The discussion of the moral dilemma itself is one of the methods of discussion in the cognitive moral development approach by inviting students to discuss moral issues. It is expected that students can learn to take responsibility for the choices as well as the words that they express in front of their colleagues in the discussion. ${ }^{16}$

Without the process, discussion about moral dilemmas in case of individual cognitive moral development will not develop. The behavioral change will never occur which makes consistent potential moral behavior is also difficult to occur. Therefore, internalization of values including one of the moderate values of Islam can be done by inviting students to discuss moral dilemmas to encourage the development of individual cognitive morals.

The internalization strategy of moderate values of Islam implemented by the KBM as described above can be simply described in the following chart:

\footnotetext{
16 Noviana Dewi and Nanik Prihartanti, "Metode Biblioterapi dan Diskusi Dilema Moral untuk Pengembangan Karakter Tanggungjawab," Jurnal Psikologi, vol. 41, no. 1 (August, 2014): 47-59, https://doi.org/10.22146/jpsi.6957. 


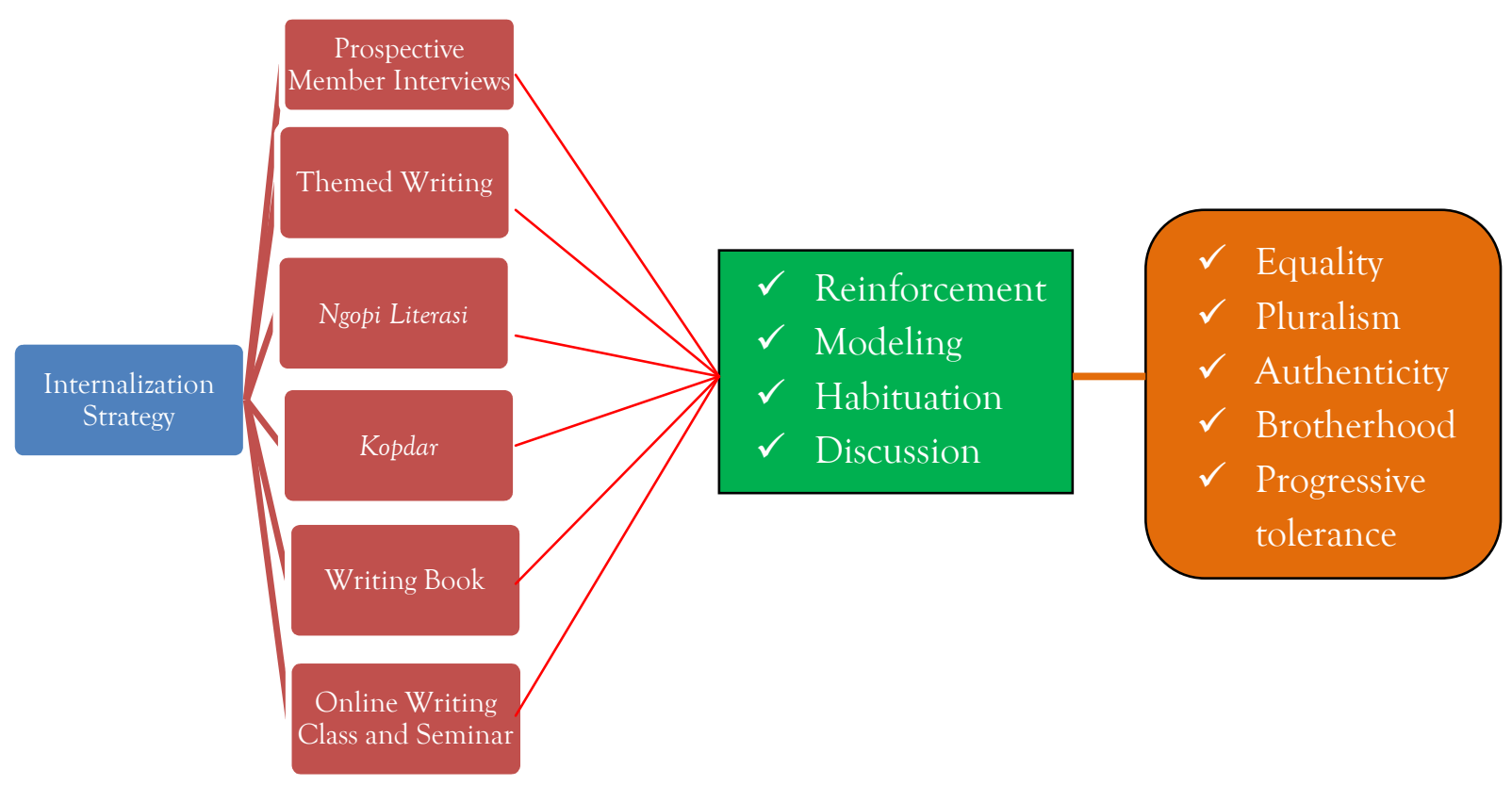

\section{Conclusion}

The internalization of moderate values of Islam does not become a complete, stand-alone program at KBM. However, it becomes a hidden curriculum and culture in daily interactions. The underlying thing is the value of equality which is the basic value of the philosophy of the establishment of KBM. From this value, KBM developed other values such as pluralism, authenticity, brotherhood, tolerance, and progressiveness. The linkages of these six values shape the culture of moderation at the KBM. The internalization strategy was pursued by KBM by: (1) reinforcing members who send their writings following the provisions not offending SARA elements and not containing hoaxes; (2) modeling by the management by providing examples of how to produce work that is friendly to differences and contains matters things that are useful for others; (3) conducting discussion both internally at the management during the meeting, and together with members during the kopdar program and reviewing the work of members in the WhatsApp group; (4) training the members whose writing offends the SARA issue and contains hoaxes; and (5) conducting habituation that is integrated with the implementation of the main programs of the KBM.

Some steps were taken by KBM in civilizing literacy in rural areas as well as integrating it with the internalization of moderate values of Islam have an impact on its members. This can be seen at least from the writings This can be seen at least from the writings of KBM members who are not related to sensitive matters such as SARA issues and also do not contain 
information that does not have authoritative sources. Moreover, KBM members are naturally accustomed to working by creating original words without plagiarizing the work of others.

\section{References}

Andriyos, Benny. "Menag: Moderasi Beragama, Jantung Kemenag." Kemenag, July 10, 2019, http://www.pendis.kemenag.go.id/new/2019/07/10/menag-moderasi-beragama-jantungkemenag/, accessed 10 July 2019.

Antoro, Billy. 2017. Gerakan Literasi Sekolah dari Pucuk hingga Akar: Sebuah Refleksi. Jakarta: Kementerian Pendidikan dan Kebudayaan.

Cahyani, Berliana Henu. 2012. "Peran Reinforcement dalam Kemampuan Regulasi Diri pada Siswa SD Selama di Kelas.” Jurnal Spirits, 3 (1): 1-13, https://doi.org/10.30738/spirits.v3i1.1121.

Dewi, Noviana and NanikPrihartanti. 2014. "Metode Biblioterapi dan Diskusi Dilema Moral untuk Pengembangan Karakter Tanggungjawab.” Jurnal Psikologi, 41 (1): 47-59, https://doi.org/10.22146/jpsi.6957.

Futaqi, Sauqi. 2018. "Konstruksi Moderasi Islam (Wasathiyyah) dalam Kurikulum Pendidikan Islam.” Proceedings of $2^{\text {nd }}$ Annual Conference for Muslim Scholars. Surabaya: Kopertais Wilayah IV.

Hakim, Muhammad Aziz, et. al. 2017. Moderasi Islam: Deradikalisasi, Deideologisasi dan Kontribusi untuk NKRI. Tulungagung: IAIN Tulungagung Press.

Juditha, Christiany. 2019. "Literasi Informasi Melawan Hoaks Bidang Kesehatan di Komunitas Online.” Jurnal Ilmu Komunikasi, 16 (1): 79, https://doi.org/10.24002/jik.v16i1.1857.

Permatasari, Ane. 2015. "Membangun Kualitas Bangsa dengan Budaya Literasi." Prosiding Seminar Nasional Bulan Bahasa 2015. Bengkulu: Unit Penerbitan FKIP Universitas Bengkulu.

Satgas Gerakan Literasi Sekolah Kemendikbud. 2018. Desain Induk Gerakan Literasi Sekolah, eds. Rangesti Wiedarti and Kisyani Laksono. Jakarta: Kementerian Pendidikan dan Kebudayaan.

Sitompul, Hafsah. 2016. "Metode Keteladanan dan Pembiasaan dalam Penanaman Nilai-Nilai dan Pembentukan Sikap Pada Anak.” Darul Ilmi: Jurnal Ilmu Kependidikan dan Keislaman, 4 (1).

Superka, Douglas P., et. al. 1976. Values Education Sourcebook: Conceptual Approaches, Materials Analyses, and an Annotated Bibliography. California: Social Science Education Consortium.

Zaqiah, Qiqi Yuliati and A. Rusdiana. 2014. Pendidikan Nilai: Kajian Teori dan Praktik di Sekolah. Bandung: Pustaka Setia.

Interview:

Lutfiah Fajrianti, interview via WhatsApp, 15 October 2019, at 19.52.

Rahayu Lestari Putri, interview, Sunday, 13 October 2019, at 14.05. 